\title{
EFFECT OF PRAESTOL AS A COAGULANT-AID TO IMPROVE COAGULATION- FLOCCULATION IN DYE CONTAINING WASTEWATERS
}

\author{
NOURMORADI H. ${ }^{1}$ \\ RAHMATI Z. ${ }^{1}$ \\ JAVAHERI M. ${ }^{1}$ \\ MORADNEJADI K. ${ }^{2}$ \\ NOORIMOTLAGH Z ${ }^{3, *}$
}

\author{
${ }^{1}$ Department of Environmental Health Engineering, School of Health \\ Ilam University of Medical Sciences, Ilam, Iran \\ ${ }^{2}$ Department of Environmental Engineering \\ School of Energy and Environment, Islamic Azad University \\ Branch of Sciences and Researches, Tehran, Iran \\ ${ }^{3}$ Environmental Technologies Research Center \\ Ahvaz Jundishapur University of Medical Sciences, Ahvaz, Iran
}

Received: 05/08/20155

Accepted: 09/12/2015

Available online: 18/12/2015

*to whom all correspondence should be addressed: e-mail: z.noorimotlagh@gmail.com

\section{ABSTRACT}

This study was conducted to investigate the effect of praestol, as a coagulant-aid, to improve coagulationflocculation process in the removal of disperse red 60 from aqueous solutions. The effect of various parameters including coagulants dose (10-1000 $\left.\mathrm{mg} \mathrm{l}^{-1}\right)$, praestol dose (0-1000 $\left.\mathrm{mg} \mathrm{l}^{-1}\right)$, solution $\mathrm{pH}(3-11)$, initial dye concentration (100-500 $\mathrm{mg} \mathrm{l}^{-1}$ ), flocculation speed (30-60 rpm), flocculation time (15-30 min), settling time (5-60 $\mathrm{min})$ and ionic strength $\left(0-6 \mathrm{mg} \mathrm{l}^{-1}\right)$ was evaluated on the dye removal. The dye removal efficiency was substantially increased by using praestol in the concentration of $80 \mathrm{mg} \mathrm{l}^{-1}$ and $400 \mathrm{mg} \mathrm{I}^{-1}$ for coagulation with alum and polyaluminum chloride $(\mathrm{PACl})$, respectively. The maximum dye removal by alum coupled with praestol (Al-P) and PACl coupled with praestol (PA-P) was found to be $97.8 \%$ and $98.7 \%$, respectively that were occurred at $\mathrm{pH} 7$. The results showed that the application of PA-P or Al-P can be effectively used to remove disperse red 60 (DR 60) in aqueous solutions.

Keywords: Wastewater, Dye, Coagulation, Praestol, Alum, PACl

\section{Introduction}

In recent years, aquatic ecosystems pollution due to the irregular disposal of dye containing wastewaters has been substantially increased, especially in developing countries (Noorimotlagh et al., 2014). It has been approximated that more than 700,000 tons of various dye materials are annually produced in the world (Riera-Torres et al., 2010). Many industries including textile, dyeing, leather, rubber, plastic, carpet, food processing, pulp and paper are considered as the major sources of dye-containing wastewaters production (Soltani et al., 2014; Nourmoradi et al., 2015a). Discharge of the color wastewaters into the water bodies can reduce light penetration and then can disrupt the photosynthesis process in the aqueous environments (Anouzla et al., 2009). Moreover, most of dyes materials can cause adverse effects including allergy, dermatitis, skin irritation and cancer on human health (Anouzla et al., 2009). The presence of very low concentration of dyes (less than $1 \mathrm{mg} \mathrm{l}^{-1}$ ) in an effluent, because of the mentioned effects, is objectionable and it should be removed prior to discharging the wastewater into the environment (Sadri Moghaddam et al., 2010). Different treatment methods like adsorption, coagulation-flocculation, chemical oxidation, photo-degradation and biological conversion are applied to remove dyes from wastewaters. However, the dyes are difficult to remove by conventional treatment processes (Merzouk 
et al., 2011). Among the above procedures, coagulation-flocculation process is extensively used in removing dyes from industrial wastewaters (Huang et al., 2014b). Dyes can be removed through coagulation-flocculation without decomposition, thus no potentially detrimental and poisonous intermediate substances are created. Furthermore, the operation and maintenance (O\&M) of this process is relatively uncomplicated and cost effectiveness (Shi et al., 2007; Huang et al., 2014a). Many coagulants such as aluminum sulphate, ferric chloride and polyaluminum chloride (PACl) are extensively used in the conventional wastewater treatment process (Anouzla et al., 2009).

Table 1. Dye removal from textile wastewaters by coagulation-flocculation process.

\begin{tabular}{cccc}
\hline Type of Coagulant & Type of Dye & Color Removal (\%) & Reference \\
\hline Ferric based & Real textile wastewater & 50 & (Zahrim et al., 2011) \\
\hline Ferric chloride & Reactive dye & 12 & (Zahrim et al., 2011) \\
\hline Ferrous sulphate & Real textile wastewater & 50 & (Zahrim et al., 2011) \\
\hline Aluminium sulphate & Cotton-textile wastewater & 60 & (Selcuk, 2005) \\
\hline Ferric sulphate & Real textile wastewater & 58 & (Verma et al., 2012) \\
\hline Aluminium sulphate & Direct dye & 50 & (Zahrim et al., 2011) \\
\hline Ferrous sulphate & Real textile wastewater & 50 & (Baraoidan et al., 2007) \\
\hline
\end{tabular}

Application of these inorganic coagulants without coagulant-aid in some dye containing wastewaters has been resulted in low dye removal, Table 1 . But, using coagulant-aid, especially polymers, in the coagulation process enhances the dye removal from these wastewaters (Joo et al., 2007; Zahrim et al., 2011). Polymers have been used in water and wastewater treatment for several decades. Polymers including polyacrylamides, chitosan, polysaccharides, polyvinyl are usually employed as coagulant-aid to improve the larger flocs formation and to improve the rate of sedimentation. Polyacrylamide is a crystalline poly-functional molecule that contains a vinylic carbon-carbon double bond and an amide group. Using polyacrylamide, as a relatively low cost coagulant-aid, along with common coagulants leads to a significant increase in the solids settling velocity (Ahmad et al., 2008). Praestol is a high molecular weight and white color grainy polymer that is obtained through organic synthesis on the basis of polyacrylamids (Wira and Wira, 2006). Although PACl and alum have extensively been applied in dye removal, but, to the best of our knowledge, there was no study by common coagulants and praestol, as a coagulant aid, for the removal of dye in wastewaters. The aim of this work was to investigate the influence of praestol, as a coagulant-aid, to improve coagulation-flocculation process in the removal of a dye, disperse red 60 (DR 60), from aqueous solutions.

\section{Materials and methods}

\subsection{Materials}

Disperse red 60 (DR 60) was purchased from Alvan Sabet Co (Iran). The chemical structure and general characteristics of the dye are shown in Fig 1 and Table 2, respectively.<smiles>Nc1c(Oc2ccccc2)cc(O)c2c1C(=O)c1ccccc1C2=O</smiles>

Figure 1. The chemical structure of disperse red 60

Commercial grade of polyaluminum chloride ( $\mathrm{PACl}$ ) and aluminum sulfate (alum), coagulant agent, and praestol as a coagulant-aid were provided from Chemkimia Co (Malaysia). Other analytical grade chemicals, $\mathrm{NaOH}(98 \%), \mathrm{H}_{2} \mathrm{SO}_{4}$ (95-97\%), and $\mathrm{NaCl}$ were supplied by Merck Co (Germany). 
Table 2. The characteristics of disperse red 60 .

\begin{tabular}{|c|c|}
\hline Characteristic & DR 60 \\
\hline Generic name & Disperse Red 60 \\
\hline Chemical formula & $\mathrm{C}_{20} \mathrm{H}_{13} \mathrm{NO}_{4}$ \\
\hline Molecular weight $\left(\mathrm{g} \mathrm{mol}^{-1}\right)$ & 331.326 \\
\hline$\lambda_{\max }(\mathrm{nm})$ & 586 \\
\hline Appearance & Red powder \\
\hline
\end{tabular}

\subsection{Preparation of synthetic wastewater}

A stock dye solution of $1000 \mathrm{mg} \mathrm{l}^{-1}$ was prepared in distilled water and then was diluted according to the working concentrations. The solution $\mathrm{pH}$ was adjusted by $(0.1 \mathrm{~N}$ and $1 \mathrm{~N}) \mathrm{H}_{2} \mathrm{SO}_{4}$ and $(0.1 \mathrm{~N}$ and $1 \mathrm{~N}) \mathrm{NaOH}$. The solution $\mathrm{pH}$ was quantified using a pH meter (Metrohm Herisau Digital E 532).

\subsection{Coagulation-flocculation experiments}

Coagulation-flocculation experiments were performed in batch mode by a six beaker jar-test apparatus (Zag-Chemi, Iran). The coagulation-flocculation procedure involved rapid mixing at $200 \mathrm{rpm}$ for $2 \mathrm{~min}$ followed by slow mixing and then settling (Ahmad et al., 2008; Wu et al., 2012). One liter of the dye solution was transferred into each Plexiglas beaker. The effects of various coagulants dose $(10-1000$ $\left.\mathrm{mg}^{-1}\right)$, praestol dose $\left(10-1000 \mathrm{mg} \mathrm{l}^{-1}\right)$, solution $\mathrm{pH}(3-11)$, initial dye concentration (100-500 $\left.\mathrm{mg} \mathrm{l}^{-1}\right)$, flocculation stirring speed (30-60 rpm), flocculation mixing time (15-30 $\mathrm{min})$, settling time (5-60 $\mathrm{min}$ ) and ionic strength $\left(0-6 \mathrm{~g} \mathrm{I}^{-1}\right)$ were tested in the removal of DR 60 at room temperature $\left(24 \pm 1{ }^{\circ} \mathrm{C}\right)$. After conducting the treatment process, the supernatant was taken, at $5 \mathrm{~cm}$ below the effluent surface, to determine the dye removal efficiency. All the experiments were carried out in triplicates and the average values were applied to analyze the treatment method. The removal efficiency was calculated by Eq. (1).

$$
R(\%)=\frac{\left(C_{0}-\mathrm{Ce}\right)}{C_{0}} \times 100
$$

Where; $\mathrm{R} \mathrm{( \% )}$ is the removal efficiency of DR 60. $\mathrm{C}_{0}\left(\mathrm{mg} \mathrm{l}^{-1}\right)$ and $\mathrm{Ce}\left(\mathrm{mg} \mathrm{l}^{-1}\right)$ are the initial and equilibrium dye concentrations, respectively (Faghihian et al., 2014; Nourmoradi et al., 2015b). An UV-Vis spectrophotometer ( $\mathrm{HACH}, \mathrm{DR5000}$, USA) was used to determine DR 60 concentration at the maximum absorbance wavelength (586 nm).

\section{Results and discussion}

\subsection{Effect of praestol dose}

$\mathrm{PACl}$ and alum were used as coagulants coupled with praestol, as coagulant-aid (flocculant). The effect of the flocculant dosages $\left(0-1000 \mathrm{mg} \mathrm{l}^{-1}\right)$ were separately measured on the dye removal with a fixed dosage of alum (100 mg l-1) and PACl (100 mg l-1) and initial dye concentration of $100 \mathrm{mg} \mathrm{l}^{-1}$ at initial solution $\mathrm{pH}$ of 6 . Also, during this step, the coagulation mixing speed was $200 \mathrm{rpm}$ for $2 \mathrm{~min}$ followed by slow mixing (40 rpm for $15 \mathrm{~min}$ ) and then settling ( $30 \mathrm{~min}$ ). The results of dye removal by alum coupled with praestol (AI-P) and PACl coupled with praestol (PA-P) are shown in Fig 2. As seen, the maximum dye removal by alum and $\mathrm{PACl}$ (without praestol) was $65.8 \%$ and $0.7 \%$, respectively. The removal efficiency of dye was substantially increased by adding praestol as flocculant in the coagulation process. The dye removal was increased from $65.8 \%$ to over $98 \%$ by increasing praestol dose from 0 to $80 \mathrm{mg} \mathrm{l}^{-1}$ in coagulation process by alum (100 $\left.\mathrm{mg} \mathrm{l}^{-1}\right)$. The removal efficiency was nearly constant by increasing flocculant dose more than $80 \mathrm{mg}^{-1}$ in alum coagulation. The dye removal was also improved from $0.7 \%$ to $99 \%$ with enhancing praestol from 0 to $400 \mathrm{mg} \mathrm{l}^{-1}$ in PACl $\left(100 \mathrm{mg} \mathrm{l}^{-1}\right)$ coagulation process. The removal efficiency was not changed with increasing flocculant dose (more than $400 \mathrm{mg} \mathrm{l}^{-1}$ ) in PACl coagulation. The previous studies also showed that better dye removal could be achieved when polymer was applied in combination with 
common coagulants (Wu et al., 2012; Oladoja and Aliu, 2009). In this study, praestol doses of $80 \mathrm{mg} \mathrm{I}^{-1}$ and $400 \mathrm{mg} \mathrm{l}^{-1}$ were selected for Al-P and PA-P treatments, respectively for the rest of experiments.

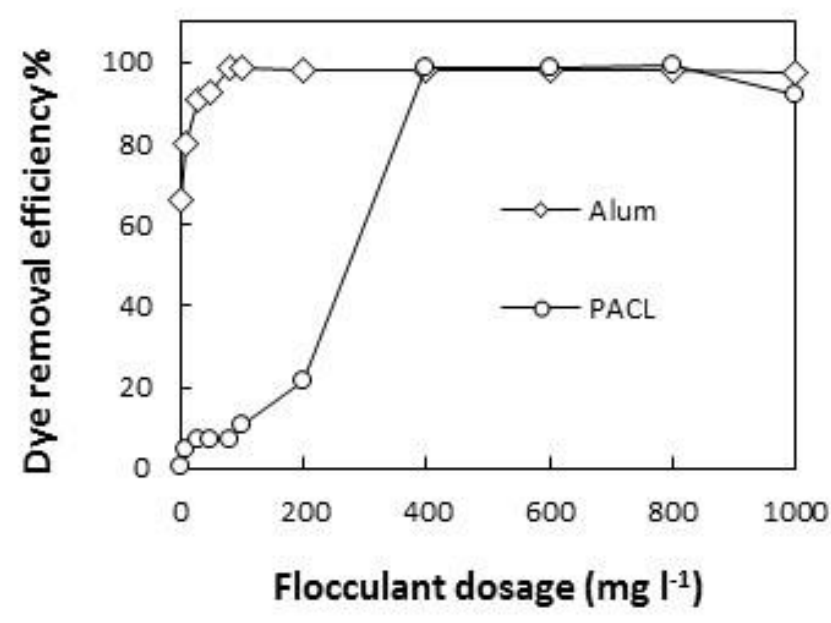

Figure 2. The effect of praestol dose on DR 60 removal

\subsection{Effect of coagulant dose}

The effect of coagulant dosage is one of the most important parameters that should be considered to determine the optimum condition in coagulation-flocculation process. Insufficient dosage or overdosing of coagulant can be resulted in the poor removal performance in the process. Therefore, it is significant to determine the most favorable dosage in order to minimize the chemical cost, sludge formation and also to acquire the optimum removal efficiency in the treatment process (Patel and Vashi, 2012). The coagulation experiments were carried out with various doses of coagulants from 10 to $1000 \mathrm{mg} \mathrm{l}^{-1}$, fixed amount of praestol dosage of $80 \mathrm{mg} \mathrm{l}^{-1}$ (for coagulation with alum) and $400 \mathrm{mg} \mathrm{l}^{-1}$ (for coagulation with $\mathrm{PACl}$ ), initial dye concentration of $100 \mathrm{mg} \mathrm{l}^{-1}$ and flocculation and settling time of 15 and 30 min, respectively. The dye removal as a function of coagulant concentration is shown in Fig 3.

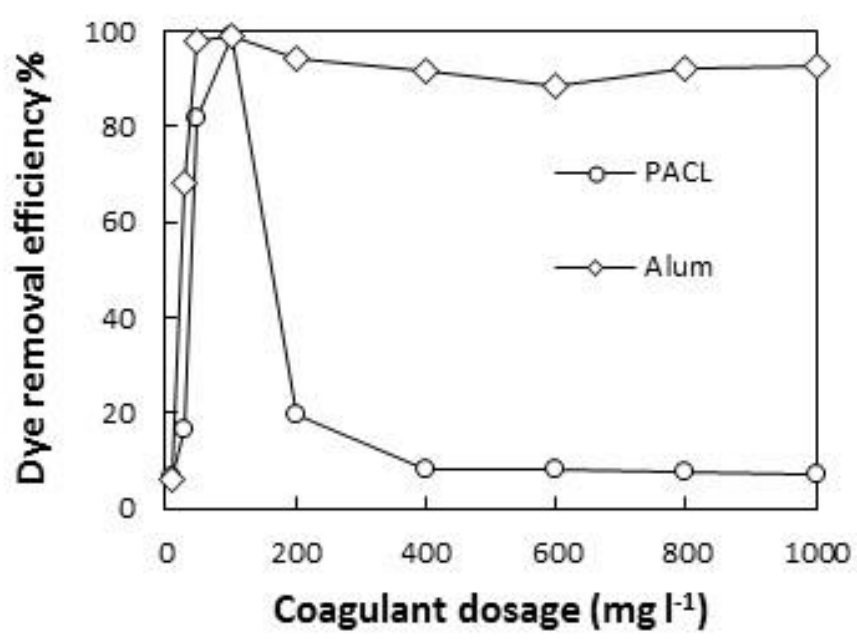

Figure 3. The effect of coagulant dose on DR 60 removal

The removal efficiency of DR 60 was increased with increasing the coagulant dose up to $50 \mathrm{mg} \mathrm{I}^{-1}$ and $100 \mathrm{mg} \mathrm{l}^{-1}$ for alum and PACl, respectively. The dye removal efficiency was decreased with increasing the 
coagulants doses greater than $50 \mathrm{mg} \mathrm{l}^{-1}$ and $100 \mathrm{mg} \mathrm{l}^{-1}$ for alum and $\mathrm{PACl}$, respectively. This decline in the dye removal efficiency may be associated to charge turnaround and destabilization of colloidal dye flocs because of overdosing of coagulant (Saritha et al., 2015).

\subsection{Effect of solution $\mathrm{pH}$}

The solution $\mathrm{pH}$ not only influences on the surface charge of coagulants, but also alters the stabilization of the dye suspension (Saritha et al., 2015). Fig. 4 depicts the effect of the solution pH (3 to 11) on the dye removal by AI-P and PA-P. The dosage of polymer as a coagulant-aid for coagulation of DR 60 by PACl and alum was $400 \mathrm{mg} \mathrm{l}^{-1}$ and $80 \mathrm{mg} \mathrm{l}^{-1}$, respectively. The coagulants doses were also $50 \mathrm{mg} \mathrm{I}^{-1}$ and $100 \mathrm{mg} \mathrm{l}^{-1}$ for alum and $\mathrm{PACl}$, respectively. As can be seen, the dye removal efficiency was increased by Al-P from $6.8 \%$ to $97.8 \%$ as the $\mathrm{pH}$ increased from 3 to 7 , and the removal efficiency was dramatically dropped to $5.8 \%$ at $\mathrm{pH} 11$.

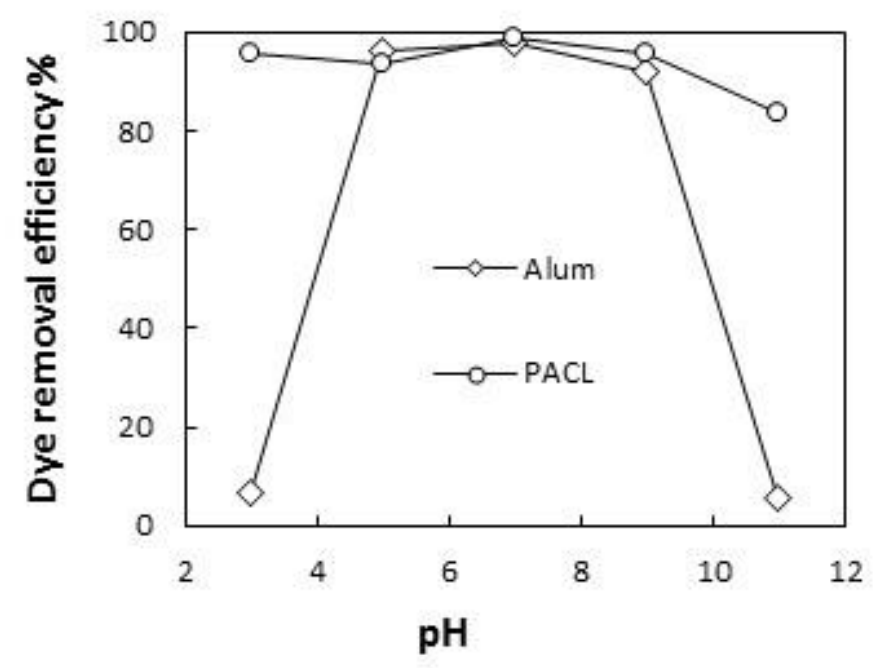

Figure 4. The effect of $\mathrm{pH}$ on $\mathrm{DR} 60$ removal

Similar trend was observed for PA-P in the solution $\mathrm{pH}$ of 3 to 7 , so, the removal efficiency was slowly increased from $95.5 \%$ to $98.7 \%$ as the $\mathrm{pH}$ increased from 3 to 7 and it was decreased to $83.7 \%$ at $\mathrm{pH} 11$. As depicted in Fig 4, the small change in removal efficiency of DR 60 dye was observed for PA-P in comparison with Al-P in all $\mathrm{pH}$ ranges. It can be concluded that PA-P compared to Al-P could operate well in wide range of $\mathrm{pH}$ for the removal of $\mathrm{DR} 60$. Several researchers reported that polyacrylamide-based polymers such as $\mathrm{PACl}$ in comparison with other common coagulants gave better dye removal efficiency in broader range of $\mathrm{pH}$ (Yeap et al., 2014; Sanghi et al., 2006; Baraoidan et al., 2007). The maximum dye removal by coagulation with Al-P (97.8\%) and PA-P (98.7\%) was obtained at $\mathrm{pH}$ 7. The most predominated species of Aluminum-based coagulants at this $\mathrm{pH}$ value $(\mathrm{pH}=7)$ are positively charged $\mathrm{Al}(\mathrm{OH})^{2+}, \mathrm{Al}_{2}(\mathrm{OH})_{2}{ }^{+}$ and also insoluble $\mathrm{Al}(\mathrm{OH})_{3}$ that are very effective to remove dye via sweep precipitation (Merzouk et al., 2011). In higher and lower sides of the optimum pH, the removal efficiency of DR 60 was reduced maybe due to the formation of more soluble forms of Aluminum (Merzouk et al., 2011). Therefore, the solution $\mathrm{pH}$ of 7 was used as the optimum pH to remove DR 60 for the rest of the experiments.

\subsection{Effect of flocculation speed and time}

Fig. 5 illustrates the effect of flocculation mixing speed and time (20-60 rpm for 15-30 min) on the dye removal efficiency. The coagulation test was conducted in alum and PACl dosages of $50 \mathrm{mg} \mathrm{I}^{-1}$ and $100 \mathrm{mg} \mathrm{l}^{-1}$, respectively, praestol dosage of $80 \mathrm{mg} \mathrm{l}^{-1}$ (for coagulation with alum) and $400 \mathrm{mg} \mathrm{l}^{-1}$ (for coagulation with PACl) and initial dye concentration of $100 \mathrm{mg} \mathrm{l}^{-1}$ at $\mathrm{pH}$ 7. As seen in Fig. 5, by increasing the flocculation speed from $20 \mathrm{rpm}$ to $40 \mathrm{rpm}$ at flocculation time of $15 \mathrm{~min}$, the dye removal efficiency was decreased. But, the dye removal at mixing time of 15 min was increased as the flocculation speed 
was increased from $40 \mathrm{rpm}$ to $60 \mathrm{rpm}$ for both the coagulants. Otherwise, the dye removal by increasing the flocculation speed from $20 \mathrm{rpm}$ to $60 \mathrm{rpm}$ was firstly increased (up to $40 \mathrm{rpm}$ ) and it was then decreased (from $40 \mathrm{rpm}$ up to $60 \mathrm{rpm}$ ) for both the coagulants at mixing time of $30 \mathrm{~min}$. The maximum dye removal of $98.1 \%$ and $99.4 \%$ was achieved for Al-P and PA-P at the flocculation speed and time of 20 rpm and 15 min, respectively.

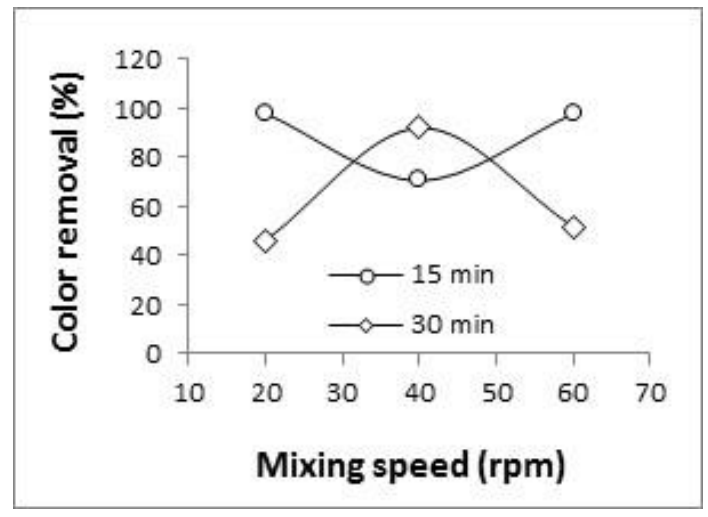

(a)

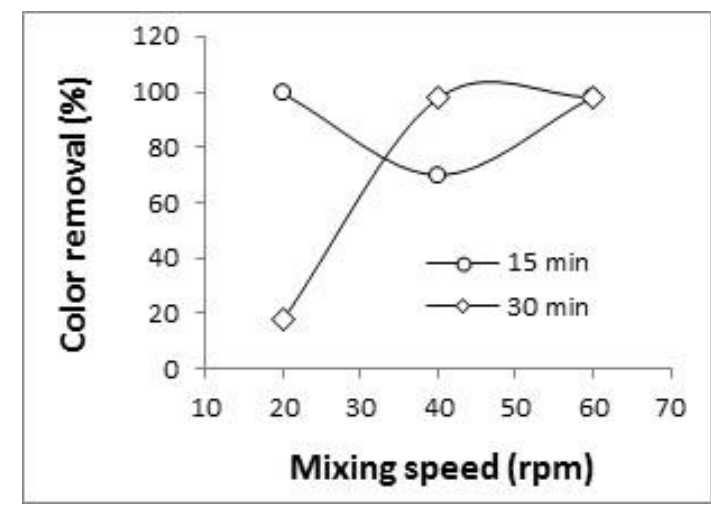

(b)

Figure 5. The effect of flocculation speed and time for DR 60 removal by a) Al-P and b) PA-P

\subsection{Effects of settling time}

In the coagulation-flocculation process, the settling time of the flocs is an important parameter because of the influence on the overall cost as well as efficiency of the process. The results of the effect of settling time on the dye removal efficiency are presented in Fig. 6.

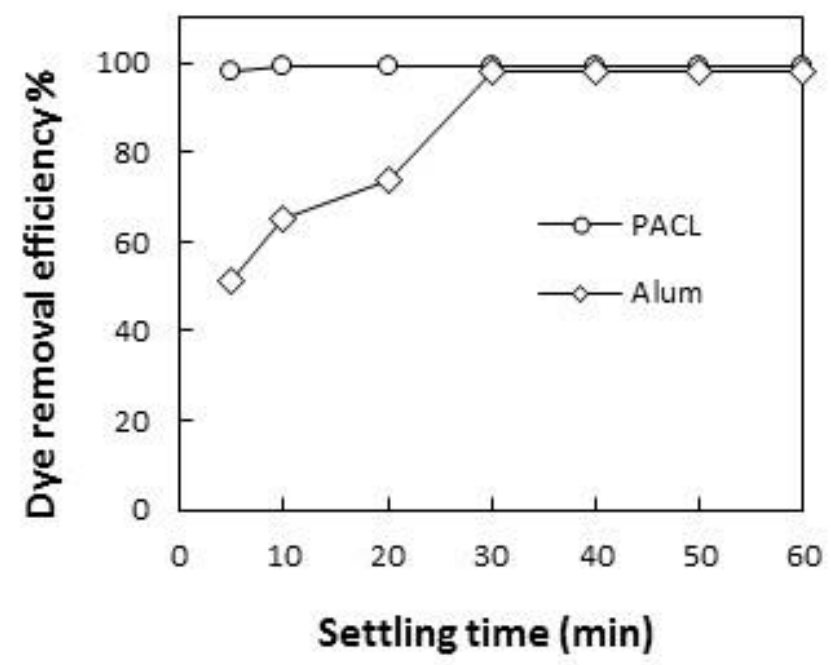

Figure 6. The optimum settling time for DR 60 removal

The addition of flocculant (praestol) had a significant effect on the settling time. This may be due to the bridging mechanism of the high molecular weight of the flocculant, praestol, which can produce more compact, high strength and larger flocs (Glover et al., 2000; Negro et al., 2006). The increase of flocs size improves the flocs settling speed and therefore reduces the settling time of the flocs. The flocs generated by PA-P settled faster than the flocs generated by Al-P. The increment in settling time more than 5 min had no effect on the dye removal efficiency by PA-P. But, in the coagulation process with Al-P, the dye removal efficiency was increased by increasing the settling time up to $30 \mathrm{~min}$ and after that it was nearly 
constant. The maximum dye removal of $98.1 \%$ over 30 min settling time and $98.2 \%$ over 5 min settling time was obtained by alum+ praestol and $\mathrm{PACl}+$ praestol, respectively.

\subsection{Effects of solution ion strength}

Various types of impurities including dissolved compounds can be found in the wastewaters from textile and dyeing industries. Ions like calcium, sodium, potassium, chloride, sulphate, carbonate, nitrate, etc are the major components of textile and dyeing wastewaters (Szyguła et al., 2008). The ionic strength can diminish the zeta potential of the solution because of its affect on the electrical charges, which causes coagulation easier. Therefore, sodium chloride may be poured in wastewater prior to coagulation in order to enhance the ionic strength of the suspension to be treated, particularly when the wastewater is polluted by non-ionic pollutants (Merzouk et al., 2011). Raising wastewater ionic strength by sodium chloride also has other advantages such as chloride anions can substantially decline the unfavorable influences of other anions on the coagulation, such as $\mathrm{SO}_{4}^{-2}$ and $\mathrm{HCO}_{3}{ }^{-}$(Merzouk et al., 2011). In this study, the effect of solution ionic strength by $\mathrm{NaCl}\left(0\right.$ to $\left.6 \mathrm{gl}^{-1}\right)$ was investigated on the coagulation process under the optimal conditions (dye concentration of $100 \mathrm{mg} \mathrm{l}^{-1}$, optimum content of praestol, alum and PACl (see Sec 3.1 to 3.3) at $\mathrm{pH}$ 7). The results are shown in Fig 7.

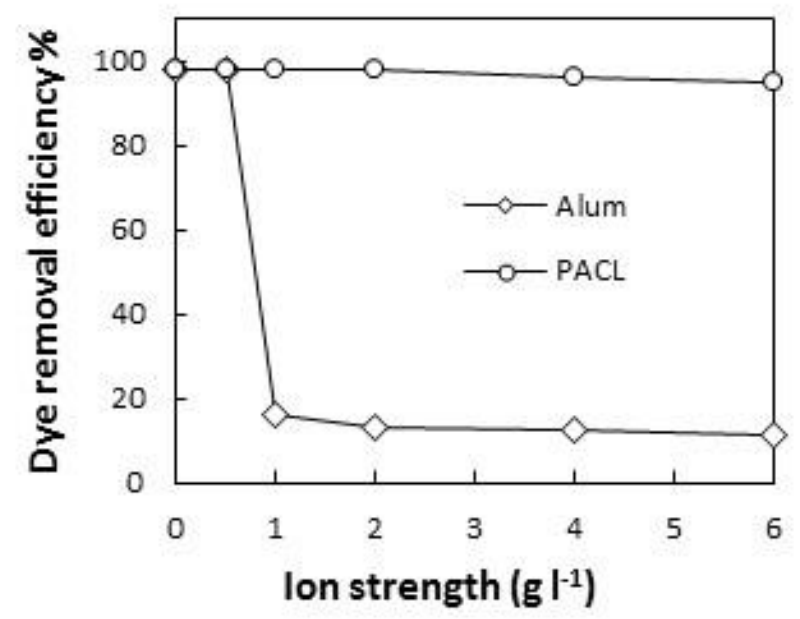

Figure 7. The optimum ion strength for DR 60 removal

As seen, increasing the solution ion strength from 0 to $6 \mathrm{~g} \mathrm{l}^{-1} \mathrm{NaCl}$ had slightly negative effect on the performance of dye removal by PA-P. The performance of dye removal by Al-P was nearly constant with increasing the solution ion strength up to $1 \mathrm{~g} \mathrm{I}^{-1} \mathrm{NaCl}$. But, the removal efficiency of Al-P was substantially decreased from $98.05 \%$ to $11.11 \%$ as the solution ion strength increased from 1 to $6 \mathrm{~g} \mathrm{l}^{-1}$, respectively. The decrease in the dye removal efficiency by increasing ion strength may be due to the absence of $\mathrm{HCO}_{3}{ }^{-}$ in the artificial wastewater. Therefore, it was concluded that $\mathrm{NaCl}$ addition into the dye solution resulted in decrease of DR 60 removal efficiency.

\section{Conclusions}

The effect of praestol, as a coagulant aid, was evaluated on the improvement of coagulation process with alum and PACl for the removal of a common disperse dye, DR 60. When praestol was used in combination with alum and $\mathrm{PACl}$, the color removal was increased at lower doses of the coagulants. The maximum dye removal by alum coupled with praestol (AI-P) and PACl coupled with praestol (PA-P) was found to be $97.8 \%$ and $98.7 \%$, respectively that were occurred at $\mathrm{pH}$ 7. The flocs generated by PA-P settled faster than the flocs generated by Al-P. Using these coagulants, especially PACl, along with praestol as a coagulantaid can effectively remove DR 60 from aqueous solutions. 


\section{Acknowledgement}

The authors are grateful to the Vice Chancellery for Research of Ilam University of Medical Sciences for the financial support of this research.

\section{References}

Ahmad A., Wong S., Teng T. and Zuhairi A. (2008), Improvement of alum and PACl coagulation by polyacrylamides (PAMs) for the treatment of pulp and paper mill wastewater, J. Taiwan Inst. Chem. Eng., 137, 510-517.

Anouzla A., Abrouki Y., Souabi S., Safi M. and Rhbal H. (2009), Colour and COD removal of disperse dye solution by a novel coagulant: application of statistical design for the optimization and regression analysis, J. Hazard. Mater., 166, 1302-1306.

Baraoidan W.A., Tun L.L., Gaspillo P.D. and Suzuki M. (2007), A Study on the Relative Performance of Different Coagulants and the Kinetics of COD in the Treatment of a Textile Bleaching and Dyeing Industrial Wastewater, ASEAN J Chem Eng., 6, 49-60.

Faghihian H., Nourmoradi H. and Shokouhi M. (2014), Removal of copper (II) and nickel (II) from aqueous media using silica aerogel modified with amino propyl triethoxysilane as an adsorbent: equilibrium, kinetic, and isotherms study, Desalin Water Treat., 52, 305-313.

Glover S.M., Yan Y.d., Jameson G.J. and Biggs S. (2000), Bridging flocculation studied by light scattering and settling, Chem. Eng. J., 80, 3-12.

Huang X., Bo X., Zhao Y., Gao B., Wang Y., Sun S., Yue Q. and Li Q. (2014a), Effects of compound bioflocculant on coagulation performance and floc properties for dye removal, Bioresour. Technol., 165, 116-121.

Huang X., Gao B., Wang Y., Yue Q., Li Q. and Zhang Y. (2014b), Coagulation performance and flocs properties of a new composite coagulant: Polytitanium-silicate-sulfate, Chem. Eng. J., 245, 173-179.

Joo D.J., Shin W.S., Choi J.H., Choi S.J., Kim M.C., Han M.H., Ha T.W. and Kim Y.H. (2007), Decolorization of reactive dyes using inorganic coagulants and synthetic polymer, Dyes Pigm., 73, 59-64.

Merzouk B., Gourich B., Madani K., Vial C. and Sekki A. (2011), Removal of a disperse red dye from synthetic wastewater by chemical coagulation and continuous electrocoagulation. A comparative study, Desalination., 272, 246-253.

Negro C., Sánchez L.M., Fuente E., Blanco Á. and Tijero J. (2006), Polyacrylamide induced flocculation of a cement suspension, Chem. Eng. J., 61, 2522-2532.

Noorimotlagh Z., Darvishi Cheshmeh Soltani R., Khataee A., Shahriyar S. and Nourmoradi H. (2014), Adsorption of a textile dye in aqueous phase using mesoporous activated carbon prepared from Iranian milk vetch, J. Taiwan Inst. Chem. Eng., 45, 1783-91.

Nourmoradi H., Ghiasvand A. and Noorimotlagh Z. (2015a), Removal of methylene blue and acid orange 7 from aqueous solutions by activated carbon coated with zinc oxide ( $\mathrm{ZnO}$ ) nanoparticles: equilibrium, kinetic, and thermodynamic study, Desalin. Water Treat., 55, 252-262.

Nourmoradi H., Zabihollahi S. and Pourzamani HR. (2015b), Removal of a common textile dye, navy blue (NB), from aqueous solutions by combined process of coagulation-flocculation followed by adsorption, Desalin Water Treat., 1-12. Doi:10.1080/19443994.2014.1003102.

Oladoja N.A. and Aliu Y.D. (2009), Snail shell as coagulant aid in the alum precipitation of malachite green from aqua system, J. Hazard. Mater., 164, 1496-1502.

Patel H. and Vashi R. (2012), Removal of Congo Red dye from its aqueous solution using natural coagulants, J. Saudi Chem. Soc., 16, 131-136.

Riera-Torres M., Gutiérrez-Bouzán C. and Crespi M. (2010), Combination of coagulation-flocculation and nanofiltration techniques for dye removal and water reuse in textile effluents, Desalination, 252, 53-59.

Sadri Moghaddam S., Alavi Moghaddam M. and Arami M. (2010), Coagulation/flocculation process for dye removal using sludge from water treatment plant: optimization through response surface methodology, J. Hazard. Mater., 175, 651-657.

Sanghi R., Bhattacharya B., Dixit A. and Singh V. (2006), Ipomoea dasysperma seed gum: An effective natural coagulant for the decolorization of textile dye solutions, J. Environ. Manage., 81, 36-41. 
Saritha V., Srinivas N. and Vuppala N.S. (2015), Analysis and optimization of coagulation and flocculation process, Appl. Water Sci., 1-10. Doi:10.1007/s13201-014-0262-y.

Selcuk H. (2005), Decolorization and detoxification of textile wastewater by ozonation and coagulation processes, Dyes Pigm., 64, 217-222.

Shi B., Li G., Wang D., Feng C. and Tang H. (2007), Removal of direct dyes by coagulation: The performance of preformed polymeric aluminum species, J. Hazard. Mater., 143, 567-574.

Soltani R., Khorramabadi G.S. Khataee A. and Jorfi, S. (2014), Silica nanopowders/alginate composite for adsorption of lead (II) ions in aqueous solutions, J. Taiwan Inst. Chem. Eng., 45, 973-80.

Szyguła A., Guibal E., Ruiz M. and Sastre A.M. (2008), The removal of sulphonated azo-dyes by coagulation with chitosan. Colloids Surf., A., 330, 219-226.

Verma A.K., Dash R.R. and Bhunia P. (2012), A review on chemical coagulation/flocculation technologies for removal of colour from textile wastewaters, J. Environ. Manage., 93, 154-168.

Wira D. and Wira, J. (2006), Influence of flocculating agents onto the water coagulation course. Baltic Coastal Zone, J Ecol Protect Coastline, 10, 147-166.

Wu C., Wang Y., Gao B., Zhao Y. and Yue Q. (2012), Coagulation performance and floc characteristics of aluminum sulfate using sodium alginate as coagulant aid for synthetic dying wastewater treatment, Sep. Purif. Technol., 95, 180-187.

Yeap K.L., Teng T.T., Poh B.T., Morad N. and Lee K.E. (2014), Preparation and characterization of coagulation/flocculation behavior of a novel inorganic-organic hybrid polymer for reactive and disperse dyes removal, Chem. Eng. J., 243, 305-314.

Zahrim A., Tizaoui C. and Hilal N. (2011), Coagulation with polymers for nanofiltration pre-treatment of highly concentrated dyes: a review, Desalination, 266, 1-16. 